\title{
The Study on Legal Protection of Tourists Rights
}

\author{
Fang-Xia YANG*, Zhuo-Jun LIU \\ School of Political Science and Law, Jiu Jiang University, Jiu Jiang 332005, China \\ No.556 Forward East Road Jiu Jiang City of Jiangxi Province in China \\ 2789735529@qq.com
}

Keywords: Tourists; Right; Legal Protection

\begin{abstract}
With the issue of tourism law, the tourism industry of our country entered to the new legally ruling era, tourism law implementation for two years, for the development of China's tourism industry provides a strong legal protection. Tourism market has been further standardized, improved the overall quality of tourism services and products, tourist complaints plummeted, improve the problems existing in the traditional tourism process. However, in the past two years, the author found that there are still some contrary to the purpose of the legislation, such as travel changes, traffic delays and other disputes, breach of the legitimate rights and interests of the event is more common.
\end{abstract}

\section{Introduction}

In the golden weeks, the number of visitors to complain about the tourist catering industry, has become the focus of widespread concern. "pricey prawn" incident is universal and typical. In some areas, the situation is even more serious, such as some tourist attractions hotel a dish of vegetables rose to 50 yuan, a tea egg to sell 5 yuan, a bottle of mineral water is usually 5 times the market price. Many tourists ironically: golden week really into a golden week, travel to eat is tiger meat, drink ginseng soup, living is heaven price. Although these words reflect the phenomenon of the tourism market is not standardized. The introduction of the "the people's Republic of China tourism law, the legitimate rights and interests of tourism fair competition in the market and protection of tourism operators, and management in accordance with the law, combating disrupt tourism market behavior, and promote China's tourism industry to develop in the direction of good health, plays a positive and important role, we are confident that these laws and regulations in the future course of development will continue to play a very active role.

\section{The Main Embodiment of the Infringement of the Legitimate Rights and Interests of Tourists}

The current laws on the protection of the legitimate rights and interests of tourists are mainly the following:

"travel law" the ninth regulation: tourists have the right to choose the tourism products and services, the right to refuse the mandatory trading behavior of tourism operators. Tourists in the personal, property safety when in danger, there is a request for assistance and protection of the rights. The person, the property is violated, the right to receive compensation according to law. The use of legal means to combat illegal operations, and safeguard the legitimate rights and interests of tourists. Under the guidance of the law, the tourism authorities shall, together with the relevant departments, formulate rules for the implementation of the Competition Law of the tourism industry, and implement the corresponding measures. Using the national laws and regulations such as "travel law", "protect the rights and interests of consumer law", to strengthen the management of domestic tourism, improve the domestic tourism business order, so that the healthy development of the domestic tourism industry. 


\section{The Specific Circumstances of the Infringement of the Legitimate Rights and Interests of Tourists}

The legitimate rights and interests of tourists cannot be protected, the domestic tourists to spend money for annoyance, the phenomenon of being slaughtered still have occurred. Some tourist scenic spot business order chaotic situation has not been effectively curbed. Some guides to the tourist attractions of the hotel people, your food, poor quality on the grounds, tours to cheaper hotel, or with a tour group to eat the so-called local specialties, due to guide and driver in order to get the rebate at the expense of visitors to damage the interests of, a large amount of waste of tourists visit time, finally resulting in tourist dissatisfaction. In accordance with the laws and regulations of our country: operators their secret to give a person a rebate of, shall be punished for the crime of bribing, as individuals in the tent kickbacks, he shall be punished for taking a bribe. The specific embodiment of the infringement of the legitimate rights and interests of tourists:

Property aspects: tourists usually carry belongings, including money, jewelry, clothing, sports equipment, etc. Business travelers may carry goods or merchandise sales sample. With the increase of the number of tourists, some tour operators continues to expand the scale, but no timely update equipment security enhanced security forces, sometimes visitors property will lost in the car or in a room, sometimes guest property will be stolen, suffered heavy losses, and tourism operators but with limited liability on the grounds of compensation only hundreds of dollars, resulting in serious damage to property rights and interests of tourists.

Personal aspects: some tour operators in order to reduce the cost and employment have not any qualification of the "black car", even the rental of knowing that there is a fault of the vehicle, the traffic accident, and "black guide limit tourists personal freedom, forcing tourists consumption, personal rights and interests and conflict caused by personal injury and seriously against the tourists. Some restaurants provide food spoilage, resulting in serious damage to the health of tourists.

\section{Analysis on the Causes of the Infringement of the Legitimate Rights and Interests of Tourists}

The first reason is the defects of the tourism operators themselves. Tourism market supply exceeds demand, the competition between the tourism operators is very fierce. In order to attract tourists and snatch resources, some tour operators began to implement a new business model On the surfacebusiness model is between tourism operators and "voluntary" market transaction behavior, tourists to enjoy "free lunch", however, tour operators to provide travel services are false propaganda tourism information, deception or force of tourism shopping, tour guide to arbitrarily change the itinerary and situations, these acts seriously infringed upon the tourism of the legitimate rights and interests. Facing the travel agent hits false tourism advertising and complex and diverse tourism management pattern, tourist travel services contract signed basically only look forward to the trip of happiness and beauty don't think tourism may bring troubles, helplessness, or even hurt.

The second reason is the relevant supporting laws and regulations are not perfect. The introduction of tourism law, people are placed high expectations, administering the journey, according to the law of tourism is a gradual process, the law is good, but the law must be strictly enforced is most important. The existing tourism law in some of the provisions of principle is too strong, operability is not strong, in the judicial practice in some practices contrary to the objective law of the development of the tourism industry and traditional habits, is inconsistent with the international practice, some one-sided emphasis on the interests of the party and disregard for the interests of the other party, unfair obviously, both against the law spirit, is not conducive to the healthy development of the tourism industry, supporting the judicial interpretation, legal laws and regulations to make up for its shortcomings.

The third reason is the lack of supervision of the regulatory authorities. Growing populations with China's economic development, people's living standards improve, the tourism industry, the tourism industry has become increasingly complex, tourism relates to many subjects, but also need to long to catch condominium together, but long supervision can easily lead to mutual shirk, and kick the ball, 
leading to many problems nobody cares or protracted, also let many unscrupulous operators drilled loopholes.

\section{The Main Measures to Safeguard the Legitimate Rights and Interests of Tourists}

In today's market economy, as a tourism enterprises and individuals, do not speak the economic benefits, regardless of the season, do not look at the market, regardless of factors such as price fluctuations, and always maintain prices unchanged, but to do it in a certain period of time (especially before and after the golden week) prices have remained relatively stable, should not ups and downs, will not be too outrageous, don't lift the impermanence and influence tourism market and tourism enterprises reputation. Secondly, the operators must be from "Orion four seasons by a winter, tourism year by three weeks" (Spring Festival, may day and national day) pure business ideas come out, solidly improve tourism reception work, to own integrity services, quality service and special services to consciously safeguard the visitors the legitimate rights and interests, integrity management as a business foothold, to promote the integrity of the enterprise culture construction, don't need to hear criticism of tourists: "golden week is cut off the week. In case of disputes, the lawsuit is expensive, time-consuming and detrimental to the corporate reputation. Tourism operators should strengthen their own construction, focusing on prevention, so that visitors in the safety of the facilities to enjoy the time away from home in this period of time, not to be hurt and violations. Tourism departments at all levels must earnestly implement the party spirit of the Fifth Plenary Session of the eighth, to implement the tourism law as the core, push forward administration according to law, to improve the tourism system of laws and regulations, improve tourism level of law enforcement, to strengthen the construction of the rule of law security for tourism, improve the tourism legal system based on the tourism law. With the tourism industry becomes more and more complicated, on the basis of "tourism law", combined with "consumer protection law", the travel agency regulations, "and other relevant laws and regulations, China can learn from foreign legislation, in the refinement of relevant industry on the basis of legal norms on the subject of Tourism management norms of behavior. In federal and state laws in the United States, for example, the law requires restaurants to make a public announcement about the food they sell, and a false announcement will lead to sanctions. Foreign tourists' mental damage compensation legislation experience, but also worth our reference.

In tourism operators default or due to the reasons lead to the tourists' lawful rights and interests have been infringed should take "strict liability", "strict liability" also known as the principle of no fault liability, refers to whether there is a fault, as long as the harm is caused to another person should bear the responsibility for compensation. In the third party caused by tourism authority violated should take the principle of fault liability, it is according to the criteria of the fault of the perpetrator, and to judge the damage should bear tort liability imputation principle. Generally speaking, the third person's tort, the tour operator is at fault, therefore, can be directly on the basis of the principle of fault held its liability. But only to adapt to the requirements of his fault bear responsibility. This principle also applies to tort causes of concurrence, namely, the damage was caused by the common causes of tourism operators and the third. In both parties have no fault, or cannot find the person or the infringement of human weakness, to assume liability for compensation, it can be applied to the principle of fairness. Fair principle, also known as equitable liability principle is refers to in both parties to the detriment of no fault, legal and no special provisions apply to the no fault liability, by the court according to the concept of justice order the offender of the victim's property damage to appropriate compensation, by a kind of imputation parties shall share the loss and reasonable manner.

No relief, no right. In the legal relations of tourism, is the legitimate rights and interests of tourists. Although many legal provisions of relevant protective measures. But the tort dispute does exist and tourism. Although it is not possible to eliminate the controversy, but "it" should be effective. In order to save time, improve efficiency, reduce the loss, the legitimate rights and interests of tourists are violated, often choose to consultation or mediation, some in the travel contract also agreed to arbitration as a dispute processing necessary link), and these disputes treatment although convenient, 
quick, but does not have a final and thoroughness, the legitimate rights and interests of tourists may not timely and reasonable remedy. Therefore, in the process of dealing with disputes should be given priority to litigation. The positive transformation of government functions, to protect the rights and interests of tourists as the starting point and the home to perform government functions; coordination of tourism related functions, various measures to implement the provisions of the "tourism law". On the one hand to strengthen the supervision of tourism operators. Tourism operators legitimate rights and interests of tourists affected. It is important to enhance the supervision of tourism operators. Tourism competent departments should strengthen the management qualifications, business scope, advertising and supervision of tourism operators, but also to strengthen the supervision of tourism services such as tour guides, drivers. On the other hand, to strengthen the supervision of the tourism market. Tourism authorities should continue to improve tourism specialization, the degree of marketization, to take a series of incentives and punishment measures to promote tourism operators to improve service efficiency, enhance service quality, update the concept of enterprise. The National Tourism Administration recently delisted processing seriously on some issues to the scenic spot is a good move. Legal literacy is a citizen must have the quality in a society ruled by law. The tourists should keep pace with the times, good at learning, keep pace with the times, enhance the awareness of the law. When in the process of tourism disputes cannot by emotional, blind impulse, may lead to the escalation of conflicts, avoid from simply property damage evolution for the personal injury of the malignant event, in accordance with the law to safeguard their legitimate rights and interests.

The key lies in the implementation of the law, the implementation of the tourism law is a gradual process, the law alone is not enough, we need to protect the legitimate rights and interests of tourists, to achieve a happy tourism is still a long way to go.

\section{References}

[1] Zhao Jingyan. A study on the legal protection of tourists' rights and interests.Southwest University of Political Science and Law, 2014

[2] Jiang Binghui. Tourism case analysis and Revelation. China Tourism Publishing House, BeiJing, 2013.

[3] Information on http://www.law-lib.com/law/law_view.asp?id=417109 